\begin{tabular}{ccc}
\hline International Journal of Engineering \& Technology, 7 (4.7) (2018) $481-485$ \\
SPC & Website www.sciencepubco.com/index.php/IJET \\
Research paper & Technology \\
\hline
\end{tabular}

\title{
Analysis of Hybrid Power Plant Technology Using Data Weather in North Sumatera
}

\author{
Rimbawati $^{1}$, Abdul Azis Hutasuhut ${ }^{1}$, Yusniati Chaniago \\ ${ }^{1}$ Faculty of Engineering University of Muhammadiyah Sumatera Utara \\ ${ }^{2}$ Faculty of Engineering, Islamic University of North Sumatra (UISU) \\ *Corresponding authorE-mail: rimbawati@umsu.ac.id
}

\begin{abstract}
North Sumatera which has areas of extreme enough 0-350 altitude above sea stretching from the coast of the Strait of Malaka to the Bukit Barisan mountains, resulting in some very isolated areas and may not be covered by the electricity supply ongride. It is very necessary to conduct basic research on the application of hybrid power generation technologies to meet the lighting facilities in remote villages. After surveying potential at three points, namely: the lowlands, plains and plateaus. From the data analysis shows that, forLowland rainfall amounts average of $166 \mathrm{~mm} / \mathrm{month}$, solar irradiance an average of $185.78 \mathrm{Wh} / \mathrm{m}^{2} /$ day and an average wind speed of $2.68 \mathrm{knots}$. Furthermore, to the plains of moderate rainfall average of $176 \mathrm{~mm} / \mathrm{month}$, the intensity of solar irradiance $176 \mathrm{Wh} / \mathrm{m}^{2} /$ day and wind speeds average 2,32 Knot, while the highlands rainfall average ranges from $171 \mathrm{~mm} / \mathrm{month}$, the intensity of solar irradiance $181.09 \mathrm{Wh} / \mathrm{m} 2 / \mathrm{day}$ as well as wind speed 2.5 knots. This shows North Sumatera province is potential to develop a hybrid power generation technologies (microhydro, solar, wind and battery) to support the accelerated development of the villages.
\end{abstract}

Keywords: Hybrid, microhydro, solar, wind

\section{Introduction}

Indonesia has a large enough Renewable Energy Potential, among others micro hydro of $450 \mathrm{MW}$, Biomass $50 \mathrm{GW}$, solar energy of $4.80 \mathrm{kWh} / \mathrm{m}^{2} /$ day, energy wind $3-6 \mathrm{~m} / \mathrm{s}$ and $3 \mathrm{GW}$ of nuclear energy. Based on Presidential Decree No. 5 of 2006 on National Energy Policy, the government said that the contribution of renewable energy in the mix of national primary energy in 2025 amounted to $17 \%$ with the composition of biofuels of $5 \%$, Geothermal $5 \%$, biomass, nuclear, water, solar, and wind $5 \%$, and liquefied coal by $2 \%$. Government increased the installed capacity of micro hydro power plants be $2,846 \mathrm{MW}$ by 2025 , biomass amounting to 180 MW in 2020, wind $0.97 \mathrm{GW}$ in 2025, $0.87 \mathrm{GW}$ of solar by 2024 and $4.2 \mathrm{GW}$ of nuclear by 2024[1].

Has become imperative for energy experts and engineers to search for renewable energy sources such as solar, wind, geothermal, ocean and biomass as a sustainable alternative, cost-effective and environmentally friendly for conventional energy sources. Therefore, research on the availability of renewable energy sources continues to be done by merging multiple sources of generation [2]. Several factors must be considered before implementing renewable energy sources is to measure accurately the potential resources available, among others: the intensity of sunlight, wind speed average / year, the availability of biomass and water resources in a region [3], From these considerations, the study conducted micro hydro power plant to find the best solutions and realistic in its use, from the analysis results obtained that micro hydro power plants is very feasible to be developed as one of the new and renewable energy sources are very reliable [4], To support this then created a prototype micro hydro easy calculation to determine the cost, scale and effectiveness of these technologies [5].
Not only on the technology of micro hydro, solar energy utilization is also growing significantly worldwide. Indonesia as a developing country has been conducting various studies related to the utilization of solar power.Although Indonesia is known as a tropical country rich in sunshine, but there is a lot of data and information available on solar radiation in an area that could be converted into energy. Data and information are very important in the design of solar energy systems, especially in the choice of technology. For meet the needs of such information, can utilize satellite data bases that are widely available online either free or paid. The data is then interpreted in the form of solar energy potential map. Further research to build up a map of potential solar energy using solar radiation data base of satellite image processing results obtained from the Surface Meteorology and Solar Energy (SSE), belonging to the National Aeronautics and Space Administration (NASA)[6], Then proceed analysis [7] about the potential of solar power in Indonesia. Based on a study using the MARKAL model and concluded thatif it is assumed PV investment costs are considered constant 1650 US $\$ / \mathrm{kW}$ after 2010, PV start economically viable in Indonesia.

Research on the optimization of renewable energy system in remote areas by combining some of the potential of renewable energy such as solar, wind and micro-hydro through hybridization concept of renewable energy sources based modeling and simulation using HOMER program has been carried out in India. This model is designed to provide optimal system configuration based on data / hour for energy supply and use.From the simulation results it was found that renewable energy sources will replace conventional energy sources and would be a viable solution is used for power distribution stand alone remote areas [8], Combining renewable energy sources in hybrid systems can provide power supplies that are more economical, environmentally friendly and reliable in all conditions of load demand compared with the use of a single system. 
One of the most important problems in the operation of the hybrid system is how to optimize the measurement system components to meet all requirements of the load with the possibility of investment and operating costs to a minimum. Thus, the economic barrier to the penetration of renewable energy better insurmountable[9]. Other studies hybrid system power plant, utilizing renewable energy, combined with diesel generators as backup power for rural electricity services (rural area) in Enggano, where the area is rich in sunshine with an average annual $4,91 \mathrm{kWh} / \mathrm{m} 2 /$ day, and there is also a river with a fairly high discharge, ie at Kuala Sungai Besar with an annual average discharge of $12,13 \mathrm{~m}^{3} / \mathrm{s}$. The results of the simulation and optimization HOMER showed that overall optimum system to be applied in the study area within 25 years of the project is the integration of hydro power plant, solar plants and diesel generators. At the optimum conditions, the contribution of $78 \%$ by hydro power, solar power $12 \%$, and $10 \%$ diesel generator with a net present value (net present cost, NPC) for \$ 904835 [10].

One recommendation is that specific to the region of Sumatera in 2025 also requires the use of Photovoltaic to support the electricity supply, especially in remote areas and in isolated areas. The production of electricity from solar power by the year 2025 amounted to amounted to $17.58 \mathrm{PJ}$ (base case), where as in PVCOST, 2020 SPP has begun to play a role in electricity production of $0.67 \mathrm{PJ}$ and increased to $128.65 \mathrm{PJ}$ in 2030. The increased role PV in Sumatera as a result of the age of the diesel in the region are old, and their strategic plans of local governments to meet the electricity needs by making use of local energy sources such as mini/micro hydro and solar energy since 2005[7].

Next several technological scenarios hybrids also do by combining $\mathrm{PV} /$ wind, PV/ fuel cells, wind/ batteries storage, as well as the utilization of DC micro grid for the integration of different sources of electrical energy [11].

Related to that of Deli Serdang regency which has an area classified as extreme in North Sumatera with a height above sea 0-600 extends from the Malaka Strait coast to the mountains resulted in many areas that are isolated and unreachable by electric energy supply ongride. Those problems can be solved by developing a hybrid power generation technologies to support the accelerated development of the villages.

This research will conduct an analysis application of hybrid power plant technology based on weather data, so it will be a combination of plants according to the climate in the province of North Sumatera.

\section{Basis Theory}

\subsection{Solar Photovoltaic}

Solar or photovoltaic cells can form conductive semiconductor equipment electrical currents that can directly convert solar energy into electrical energy in an efficient form. The photovoltaic effect was discovered by Becquerel in 1839, where Becquerel detects the presence of photo-voltage when the sunlight on the electrode in an electrolyte solution.Selanjunya research solar radiation measurement techniques performed by Badosa, 2014 [12], Utilization of Solar Cells as Alternative Power Plant in several regions in Indonesia have been carried out[13], Economic calculation was also conducted to determine the feasibility of its use[14], Besides this, solar power can also be used as a producer of heat (solar thermal) that can be used for household and industry [15].

\subsection{Wind}

Wind power is one of the abundant renewable energy sources and environmentally friendly for suppressing emission of $\mathrm{CO} 2$, therefore we can obtain an unlimited cheap electricity from wind energy [16], In the utilization of wind power in a region it must be preceded by the survey related to the wind speed to determine the type of turbine that will be used. Because the wind speed in Indonesia is quite low then turbines are generally used are the type of vertical
(Savonius) [17] [18], Aside from the type of vertical, horizontal type also be examined for use in Indonesia [19].

\subsubsection{Hybrid Power System}

A Hybrid Renewable Energy System (HRES) are typically constructed of: (1) an inverter with a continuous power rating of $60 \%$ of the power load, (2) one or two engines and diesel generators that normally has a capacity equal to 1.5 times the rated power inverter and equipped with automatic control system, (3) storage systems that are biased in the form of a battery bank leadacid with a storage capacity of a certain minimum, (4) a system of renewable energy generation such as photovoltaic include regulators, and (5) based control system microprocessor for monitoring and automation of system management, Sukarman and Othman [20].

Various components hres system is assembled in several configurations, namely: (1) series hybrid system, (2) switched hybrid system, and (3) parallel hybrid system [21], Economic calculation hybrid plant utilization for remote areas is done by Petrakolpoulou, 2016[22], In controlling the required Design of Multi-Input control DC-DC Converter Systems Turbine Hybrid Wind And Solar Cells Using Fuzzy Logic Control for Low Voltage [23], Assessment and evaluation of plant performance standalone [24] and the integration of Hybrid power [25].

Parallel hybrid system use an inverter in both directions (bi-directional) that can function as an inverter (to change the DC power into $\mathrm{AC}$ ) and as a charger and regulator (convert AC power into DC). When load power lower than the power battery bank, the load is supplied by the battery through the bi-directional inverter (which functions as an inverter), while the diesel generator is extinguished. At the time of the load power exceeds the battery but smaller than power diesel generators, diesel generator turned on to supply the load and charge the battery with excess power. At this time bi-directional inverter and charger functions as a regulator. At the time of load power is higher than the diesel generator power, keep supplying diesel generator load while the bi-directional inverter back to work into the inverter and then together in parallel to supply the load. Configuring parallel hybrid system has several advantages, among others: (1) the load can be optimally satisfied, (2) the efficiency of the diesel generator high, thereby reducing maintenance costs, and (3) the size of the diesel generators and other components can be minimized, thereby reducing investment costs[21].

\section{Methodology}

This research was conducted in the province of North Sumatra in February to July 2018. The research data is secondary data from Sampali Climatology Station coordinates of 3.62 LU; 98.7 BT and Kualanamu Meteorological Station coordinates LU 03'38'25, 098'52'43 'BT form: the data of rainfall, solar radiation data and data kecpatan wind. Furthermore, the data in the input with mikrosoft excel in order to know the average value of each sample location. Then a linear regression analysis to determine the best potential if developed regions renewable energy generation.

\section{Results and Discussion}

\subsection{Data Renewable Energy Potential by Region}

1) Lowland

These data were taken to analyze the potential contained in the coastal area of North Sumatera, particularly the Deli Serdang which has quite a lot of villages. Based on data from the Meteorological and Geophysics Agency Kualanamu heaviest rainfall occurs in August, September and October during the year, meaning that the potential of the water would overflow the month. Furthermore, the intensity of solar radiation is highest in April, June and October, which means that the potential of the sun will be very good for the 
month. While the greatest wind potential occurred in February, March and December. From these data it can be concluded that the entire coastal region in the wake potential of hybrid plants.

Table 1: Data Energy Potential Lowland

\begin{tabular}{|c|c|c|c|c|c|c|c|c|c|c|c|c|c|}
\hline \multicolumn{14}{|c|}{ Energy Potential Data in the Lowlands } \\
\hline & \multicolumn{13}{|c|}{ month } \\
\hline Potency & Jan & $\mathrm{Feb}$ & March & Apr & May & June & July & Augt & Sept & Oct & Nov & Dec & average \\
\hline Rainfall (mm/ Month) & 133 & 34 & 53 & 84 & 163 & 138 & 174 & 236 & 468 & 277 & 156 & 194 & 176 \\
\hline Solar Irradiance $\left(\mathrm{W} / \mathrm{m}^{2}\right.$ & 168.5 & 191 & 178 & 209 & 154 & 182.5 & 196 & 176.5 & 178.5 & 183.5 & 141 & 153 & 175.96 \\
\hline Wind Velocity $(\mathrm{m} / \mathrm{s})$ & $2: 15$ & $2: 45$ & 2.4333 & 2.4 & $2: 15$ & 2.4 & $2: 25$ & $2: 25$ & 2.3 & 2.2 & 2.3 & $2: 55$ & $2: 32$ \\
\hline
\end{tabular}

2) Medium plains

Based on data obtained from Sampali Climatology Station, on the plains was the highest rainfall occurs in September and October which resulted in the abundant flow of water in all areas. While the intensity of solar radiation will be maximal in February, March and September throughout the year as well as the largest wind potential there in October and December throughout the year.

Table 2: Data Average Plains Energy Potential

\begin{tabular}{|c|c|c|c|c|c|c|c|c|c|c|c|c|c|}
\hline \multicolumn{14}{|c|}{ Data on the Energy Potential of the Medium Plain } \\
\hline \multicolumn{14}{|c|}{ month } \\
\hline Potency & Jan & Feb & March & Apr & May & June & July & Augt & Sept & Oct & Nov & Dec & average \\
\hline Rainfall (mm / Month) & 170 & 62 & 44 & 40 & 136 & 90 & 133 & 156 & 408 & 367 & 189 & 202 & 166 \\
\hline Solar Irradiance $\left(\mathrm{W} / \mathrm{m}^{2}\right)$ & 168.42 & 211 & 207.13 & 183 & 185.5 & 187.3 & 179 & 183.6 & 213.7 & 194.13 & 157.1 & 159.8 & 185.78 \\
\hline Wind Velocity $(\mathrm{m} / \mathrm{s})$ & 2.1 & 2.6 & 2.4333 & $2: 35$ & $2: 35$ & $2: 35$ & $2: 35$ & $2: 35$ & $2: 35$ & 4.4 & $2: 35$ & $4: 15$ & 2.68 \\
\hline
\end{tabular}

3) Mountainous area

Data obtained by the highlands / mountainous showed that: the highest rainfall occurs in September and October, while the high sun intensity in February, March, April and September. Furthermore, the highest wind speed there in October and December.

Table 3: Mountain Area Energy Potential Data

Potency

Rainfall (mm / Month)

Solar Irradiance $\left(\mathrm{W} / \mathrm{m}^{2}\right)$

Wind Velocity $(\mathrm{m} / \mathrm{s})$
Table 3: Mountain Area Energy Potential Data
Mountain Area Energy Potential Data

$\begin{array}{rr}\text { Jan } & \text { Feb } \\ 152 & 48 \\ 168.46 & 201 \\ 2.1 & 2.5\end{array}$

May June July

$\begin{array}{rrr}149 & 114 & 153\end{array}$

$169.7 \quad 187.6 \quad 187$

$192.54 \quad 196$

2.3

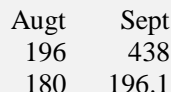

$196 \quad 438$

$2.3-2.3$
322

188.82

3.3

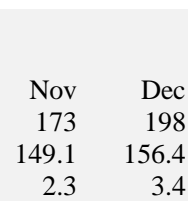

average

171

181.09

\subsection{Comparison of Renewable Energy Potential Based Sample Location}

\subsubsection{Potential Rainfall}

Table 4: Potential Rainfal

\begin{tabular}{l|rrrrrrrrrrrrr}
\hline \multicolumn{10}{c|}{ Rainfall (mm / Month) } \\
\hline \multicolumn{1}{c|}{ Potency } & Jan & Feb & March & Apr & May & June & July & Augt & Sept & Oct & Nov & Dec & average \\
\hline Lowland & 133 & 34 & 53 & 84 & 163 & 138 & 174 & 236 & 468 & 277 & 156 & 194 & 176 \\
medium Plain & 170 & 62 & 44 & 40 & 136 & 90 & 133 & 156 & 408 & 367 & 189 & 202 & 166 \\
mountainous area & 152 & 48 & 48 & 62 & 149 & 114 & 153 & 196 & 438 & 322 & 173 & 198 & 171
\end{tabular}

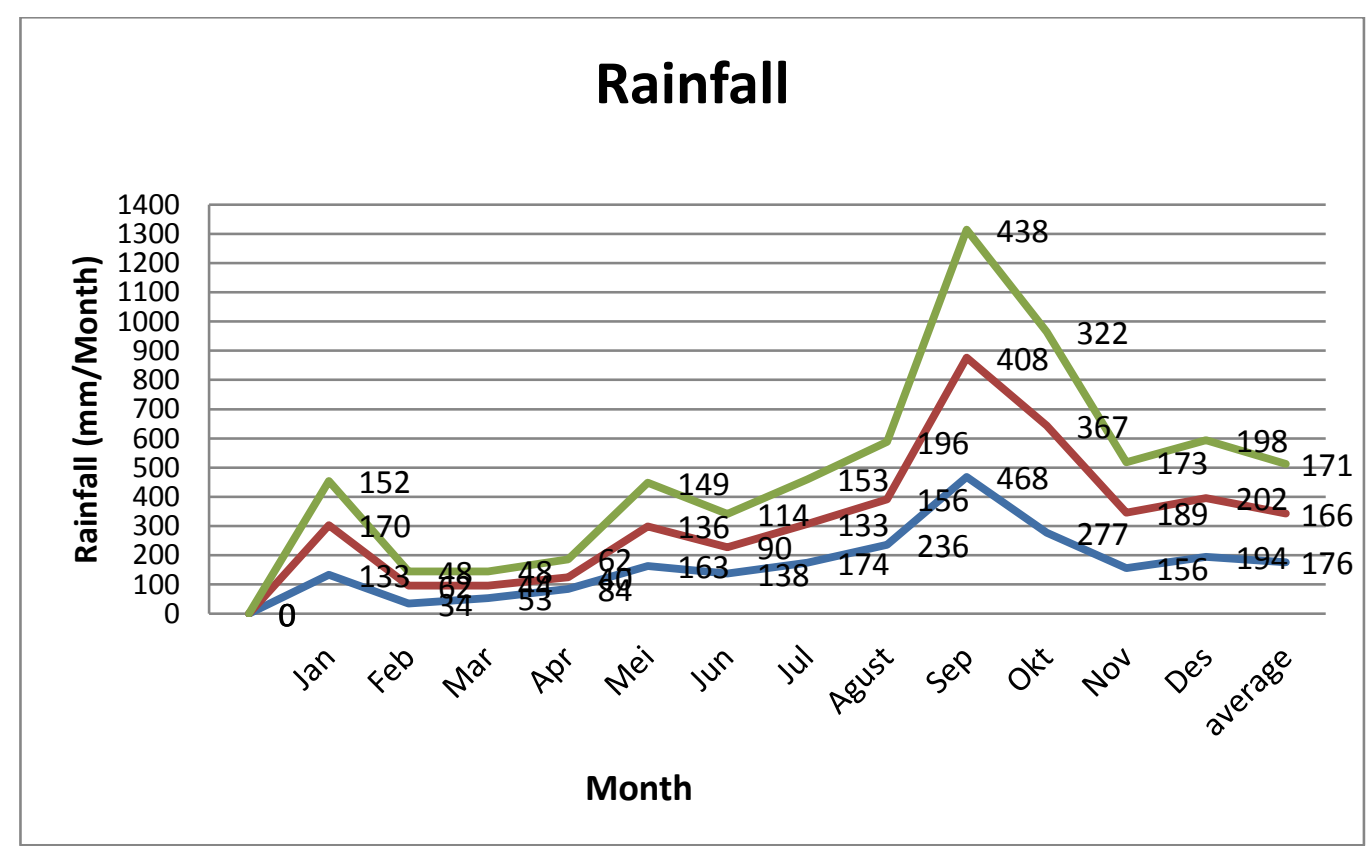

Figure 1:Rainfall Graphs Based on Sample point 
Figure 1 shows the data in September, October and November rainfall is high enough so micro hydro as base load will be maximum utilized in servicing burden of the day and night.

\subsubsection{Potential Solar Radiation Intensity}

Comparison of the light intensity between the three point samples undergo a significant difference, this is due to solar radiation in the lowlands tend not to have obstructions such as trees or plantations. While the plains have the lowest intensity is $176 \mathrm{watt} / \mathrm{m}^{2}$. Furthermore, to the highlands light intensity ranges from $181 \mathrm{Watt} / \mathrm{m}^{2}$. From table 5 can be concluded that all sample points will enable the development of hybrid power plant technology.

Table 5: Potential Solar Radiation Intensity Comparison Each sample

\begin{tabular}{|c|c|c|c|c|c|c|c|c|c|c|c|c|c|}
\hline \multicolumn{14}{|c|}{ Solar Irradiance (W / m2) } \\
\hline Potency & Jan & Feb & March & Apr & May & June & July & Augt & Sept & Oct & Nov & Dec & average \\
\hline Lowland & 169 & 191 & 178 & 209 & 154 & 183 & 196 & 177 & 179 & 184 & 141 & 153 & 176 \\
\hline medium Plain & 168 & 211 & 207 & 183 & 185 & 187 & 179 & 184 & 214 & 194 & 157 & 160 & 186 \\
\hline mountainous area & 168 & 201 & 193 & 196 & 170 & 188 & 187 & 180 & 196 & 189 & 149 & 156 & 181 \\
\hline
\end{tabular}

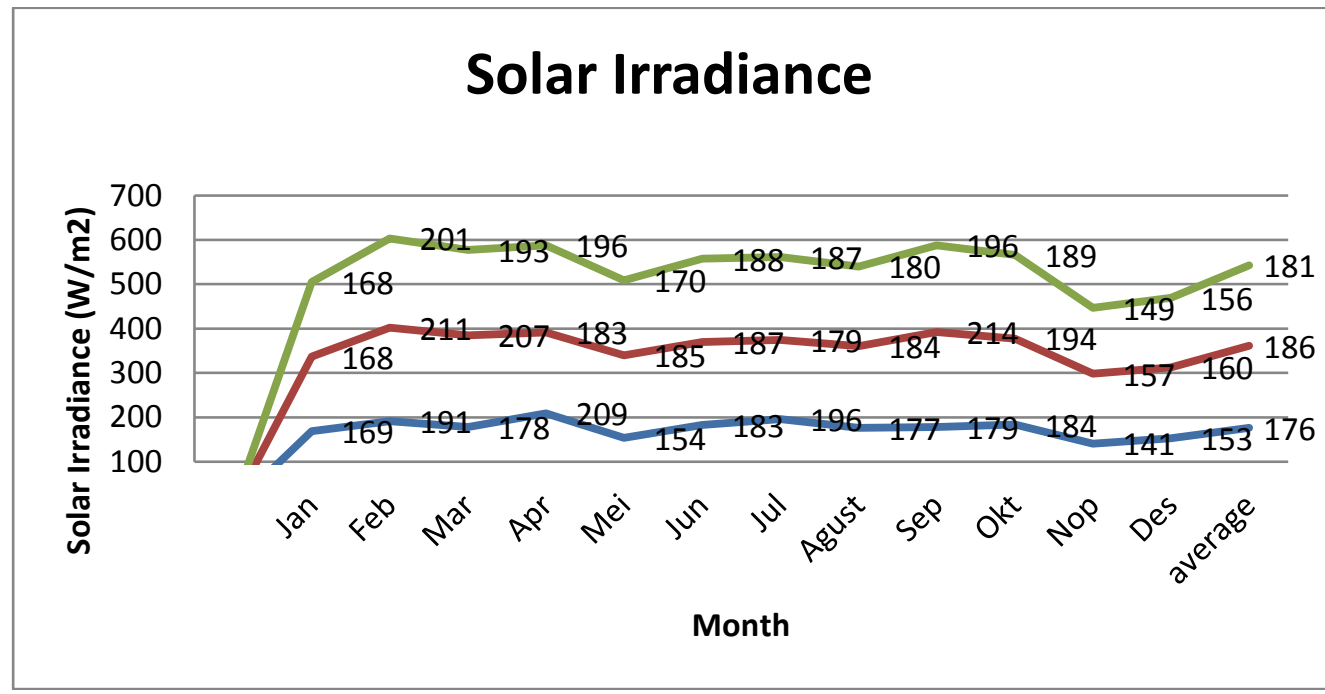

Figure 2: The intensity Solar Irradiance graph based Point Sample

\subsubsection{Potential Wind Speed}

Wind speed throughout the Indonesian region sufficient potential to be developed as a powerhouse. Data samples obtained from BMKG show that the average wind speed found at each sample point between 2.3 to 2.7 knots during the year. This potential can be seen in Table 6 below.

Table 6: Comparison of Potential Wind Speed for Each Location Sample

\begin{tabular}{l|rrrrrrrrrrrrr}
\hline \multicolumn{10}{c}{ Wind Potency $(\mathrm{m} / \mathrm{s})$} \\
\hline \multicolumn{1}{c|}{ Potency } & Jan & Feb & March & Apr & May & June & July & Augt & Sept & Oct & Nov & Dec & average \\
Lowland & 2.2 & 2.5 & 2.4 & 2.4 & 2.2 & 2.4 & 2.3 & 2.3 & 2.3 & 2.2 & 2.3 & 2.6 & 2.3 \\
medium Plain & 2.1 & 2.6 & 2.4 & 2.4 & 2.4 & 2.4 & 2.4 & 2.4 & 2.4 & 4.4 & 2.4 & 4.2 & 2.7 \\
mountainous area & 2.1 & 2.5 & 2.4 & 2.4 & 2.3 & 2.4 & 2.3 & 2.3 & 2.3 & 3.3 & 2.3 & 3.4 & 2.5
\end{tabular}

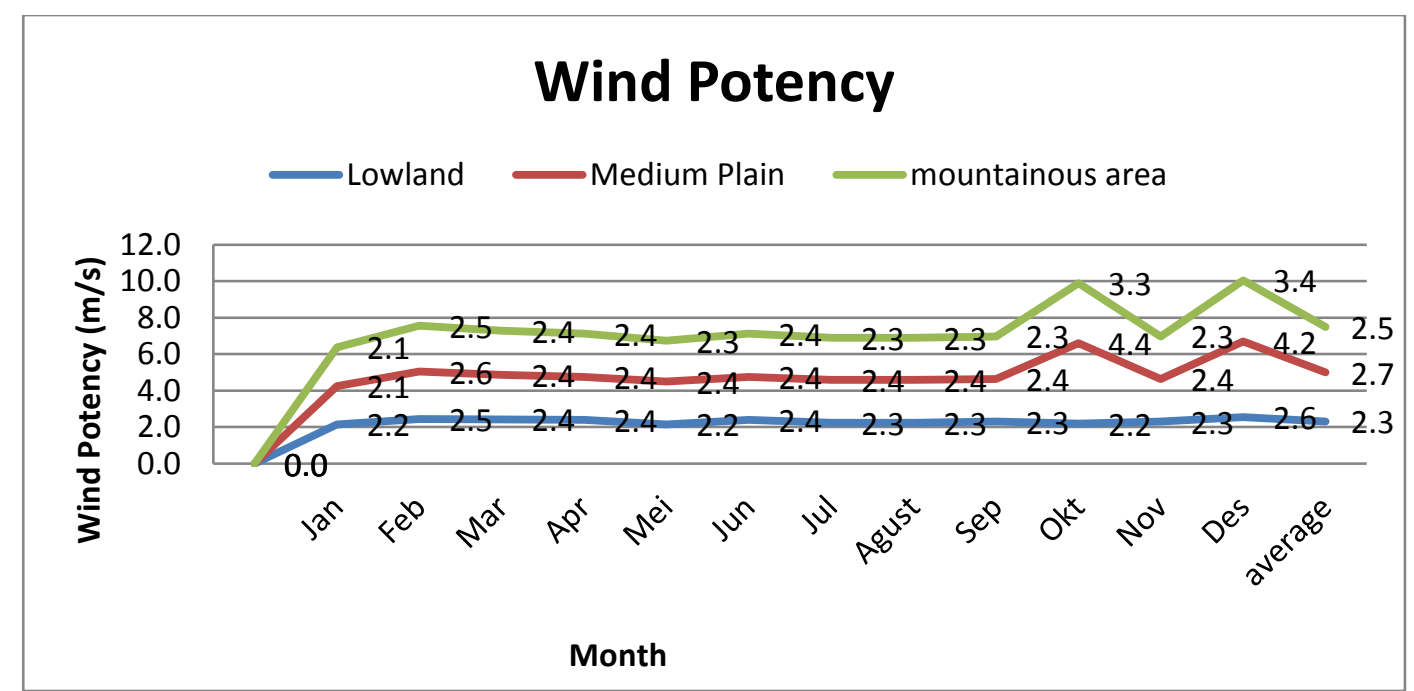

Figure 3: Wind Potency 
Figure 3 shows that all the samples are very potential to be developed as a powerhouse. The average wind speed at 2.3 knots for the region of plains/urban, $2.5 \mathrm{Knot}$ the highlands / mountains and 2.7 knots for the coastal area. This data shows the entire sample point feasible to build wind power plants. It is supported by the standard wind speed that can be used to rotate the turbine is between 1.6 to 17.1 knots.

\section{Conclusion}

After analyzing the conclusions of this study are:

Data on the potential energy that can be developed based on the height of the region, namely: lowland number average rainfall of $166 \mathrm{~mm} /$ month, solar irradiance intensity by an average of 185.78 Watt $/ \mathrm{m}^{2}$ with an average wind speed of 2.68 knots. Furthermore, to the plains of moderate rainfall average of $176 \mathrm{~mm} / \mathrm{month}$, the solar irradiance intensity $176 \mathrm{Watt} / \mathrm{m}^{2}$ with wind speeds average 2,32 Knot, while the highlands rainfall average ranges from 171 $\mathrm{mm}$, the solar irradiance intensity $181.09 \mathrm{Watt} / \mathrm{m}^{2}$ as well as wind speed 2.5 knots.

Comparison of potential rainfall at the point of sample demonstrates plains have a greater potential than in the lowlands and the mountains are: $176 \mathrm{~mm}$, the light intensity is highest in low-lying large $186 \mathrm{Watt} / \mathrm{m}^{2}$, whereas the potential wind speed highest average was in the plains low at 2.7 knots.

\section{References}

[1] KEMENKUMHAM, PP No. 5 Tahun 2006: Kebijakan energi nasional. 2006.

[2] W. Zhou, C. Lou, Z. Li, L. Lu, and H. Yang, "Current status of research on optimum sizing of stand-alone hybrid solar-wind power generation systems," Appl. Energy, vol. 87, no. 2, pp. 380-389, 2010.

[3] B. Bhandari, K. T. Lee, C. S. Lee, C. K. Song, R. K. Maskey, and S. H. Ahn, "A novel off-grid hybrid power system comprised of solar photovoltaic, wind, and hydro energy sources," Appl. Energy, vol. 133, no. December, pp. 236-242, 2014

[4] T. Hoq, U. A. Nawshad, N. Islam, K. Syfullah, and R. Rahman, "Micro Hydro Power : Promising Solution for Off-grid Renewable Energy Source," Int. J. Sci. Eng. Res., vol. 2, no. 12, pp. 2-6, 2011.

[5] G. M. P. Yadav, H. Raghavendra, K. V. B. Reddy, M. Ashok, K. C. Reddy, and P. S. G. C. S. Reddy, "An Experimental Prototype of Micro Hydro Power Generation,” vol. 3, no. 1, pp. 1-5, 2015.

[6] dan B. P. Vetri Nurliyanti, Marlina Pandin, "Pembuatan Peta Energi Surya," vol. 12, no. 1, pp. 41-49, 2014.

[7] I. Rahardjo and I. Fitriana, "Analisis Potensi Pembangkit Listrik Tenaga Surya Di Indonesia," Strateg. Penyediaan List. Nas. Dalam Rangka Mengantisipasi Pemanfaat. PLTU Batubara Skala Kecil, PLTN, dan Energi Terbarukan, P3TKKE, BPPT, Januari, pp. 43-52, 2005.

[8] D. K. Lal, B. B. Dash, and a K. Akella, "Optimization of PV / Wind / Micro-Hydro / Diesel Hybrid Power System in HOMER for the Study Area," Int. J. Electr. Eng. Informatics, vol. 3, no. 3, pp. 307$325,2011$.

[9] O. Erdinc and M. Uzunoglu, "Optimum design of hybrid renewable energy systems: Overview of different approaches," Renew. Sustain. Energy Rev., vol. 16, no. 3, pp. 1412-1425, 2012.

[10] G. H. Susilo and B. Winardi, "Diesel Dan Energi Terbarukan Di Pulau Enggano, Bengkulu," Transient, vol. 3, no. 2, pp. 237--244, 2014.

[11] J. Paska, P. Biczel, and M. Kłos, "Hybrid power systems - An effective way of utilising primary energy sources," Renew. Energy, vol. 34, no. 11, pp. 2414-2421, 2009.

[12] J. Badosa et al., "Solar irradiances measured using SPN1 radiometers: Uncertainties and clues for development," Atmos. Meas. Tech., vol. 7, no. 12, pp. 4267-4283, 2014.

[13] Y. Cahyono et al., "Pilot Project Pemanfaatan Sel Surya sebagai Pembangkit Listrik Alternatif untuk Rumah Tangga Di Pulau Gili Iyang Sumenep," vol. 2, no. 1, pp. 30-35, 2018.

[14] A. Anastasopoulou et al., "Techno-Economic Feasibility Study of Renewable Power Systems for a Small-Scale Plasma-Assisted Nitric Acid Plant in Africa."
[15] V. Sundstro, "Solar energy for electricity and fuels "," vol. 45, pp. 15-24, 2016.

[16] M. Arif and T. Hardianto, “Aplikasi Energi Terbarukan Melalui Pengukuran Potensi Angin dengan Metode Analisis Weibull pada Pantai Puger Jember," pp. 31-34.

[17] U. S. Dharma, "Pengaruh Desain Sudu Terhadap Unjuk Kerja Prototype Turbin Angin Vertical Axis Savonius," vol. 5, no. 2, pp. 138-148, 2016

[18] J. Dinamis, F. Mauritz, D. T. Mesin, F. Teknik, and U. S. Utara, "VERTIKAL AXIS SAVONIUS," vol. II, no. 12, 2013.

[19] A. Harumwidiah, "SIMULASI SISTEM PEMBANGKIT LISTRIK TENAGA ANGIN MENGGUNAKAN DOUBLY FED INDUCTION GENERATOR ( DFIG ) DENGAN BACK-TOBACK CONVERTER," no. 2, 2016.

[20] K. Sopian, M. Y. Othman, B. Yatim, and W. R. W. Daud, "Overview of National Research and Development," ISESCO Sci. Technol. Vis., vol. 1, pp. 30-36, 2005.

[21] C. V. Nayar, S. J. Phillips, W. L. James, T. L. Pryor, and D. Remmer, "Novel wind/diesel/battery hybrid energy system," Sol. Energy, vol. 51, no. 1, pp. 65-78, 1993.

[22] F. Petrakopoulou, "On the economics of stand-alone renewable hybrid power plants in remote regions," Energy Convers. Manag., vol. 118, pp. 63-74, 2016.

[23] S. Feby Agung Pamuji, "Issn : 2302 - 2949 Desain Kontrol Multi Input Dc - Dc Converter Sistem Hibrid Turbin Angin Dan Sel Surya Menggunakan Kontrol Fuzzy Logic Untuk Tegangan Rendah," J. Nas. Tek. Elektro Surabaya Vol 4, No.2 Sept. 2015 ISSN, no. 2, pp. 220-226, 2015.

[24] S. Goel and R. Sharma, "Performance evaluation of stand alone, grid connected and hybrid renewable energy systems for rural application : A comparative review Performance evaluation of stand alone, grid connected and hybrid renewable energy systems for rural application: A comparative review," Renew. Sustain. Energy Rev. vol. 78, no. November, pp. 1378-1389, 2017.

[25] M. Gökçek, "Integration of hybrid power (wind-photovoltaic-dieselbattery) and seawater reverse osmosis systems for small-scale desalination applications," Desalination, vol. 435, no. July, pp. 210 220,2018 . 